\title{
Factors That Affect the Use of Accounting Services by Micro and Small Business Enterprises in Dembi Dollo Town Administration, Oromia, Ethiopia
}

\author{
Zewdu Eskezia Gelaye \\ College of Business and Economics, Department of Accounting and Finance, Dambi Dollo \\ University, Dambi Dollo, Ethiopia
}

\begin{abstract}
The main objective of this study was to determine the factors that affect the use of accounting services by micro and small business enterprises in Dembi dollo town administration. To achieve this objective the necessary data was collected from micro and small business enterprise owners by using questionnaires. The study employed a mixed research approach i.e. both quantitative and qualitative research approaches. Stratified random sampling technique was used to select proportional number of samples from the target population of the study. The researcher used both descriptive and binary logistic regression analysis methods to analyze the raw data which was obtained from the respondents. The findings of the study was identified as family involvement with in the business operation and decision making, age of the enterprises, size of the enterprises, education level of the owners and knowledge and skill of the owners to use accounting services affects the use of accounting services by micro and small business enterprises in dembi dollo town administration. Based on the findings of the study, the researcher suggests that dembi dollo town micro and small enterprises office should give a basic business training to the concerned business enterprises about business entity concept, about the Peachtree software and its installation And finally the researcher suggests that the enterprises office should advice the owners of micro business enterprises to upgrade from micro to small because the owners of small enterprises are more likely to use accounting services than micro enterprise owners.
\end{abstract}

Keywords: Accounting services, micro \&small enterprises, family involvement, Competence, Inventory turnover period

DOI: $10.7176 / \mathrm{RJFA} / 11-1-02$

Publication date: January $31^{\text {st }} 2020$

\section{Introduction}

\subsection{Back Ground of the Study}

Due to the environmental challenges that SMEs face, SMEs require the assistance of a professional who will be able to identify competitive forces through the use of accounting services. That way, a drop in profitability as shown by a profit and loss account would be a likely indicator of new entrants to the already competitive market. A variance analysis report would show how the budgeted compared to actual achieved and hence the institution of corrective mechanisms. A cash flow report would facilitate the identification of illiquidity. The use of an accountant by SMEs would therefore be a strategic move to forestall the effect of any unseen environmental turbulence. An accountant would also help the SME to manage its taxes (Jayabalan et al, 2009)

Accounting is undeniably essential to most individuals and organizations. It serves a variety of uses in our society. Many researchers and writers have defined the role of accounting in the daily lives of people in the society. The primary purpose of accounting is simply to help people make decisions throughout their everyday lives. It provides service to different organizational bodies from a small time business to a multinational company. Baker et al, (2008) and Baysa \& Lupisan, (2008) defined accounting as a service activity. They said that the main function of accounting practices is to provide quantitative information, primarily financial in nature, about economic entities that is intended to be useful in making economic decisions. They stated that the primary duty of accountants is to render services by providing information about economic entities that is measured in terms of money.

O'Donovan et al, (2010) gave the definition of accounting as a language that communicates essential information for decision making. The author also noted that all businesses have one common factor: they all need vital information before making critical decisions. This is where accounting comes in as it plays a vital role in tracking down the activities and resources of a business and reporting back these activities in the form of relevant information. Carnegie et al.( 1999) argue that the services that fall into the category of accounting services can be identified as: Audits and assurance, including internal audit and IT audits; ii)Due diligence and business acquisitions; iii) Investigative and forensic accounting, Reviews of compliance with Australian International Financial Reporting Standards (IFRS), Adequacy of budget and forecasting processes, Taxation, including corporate, business and personal taxation consulting and compliance, advice on international transactions, indirect taxes, specialist tax needs, Business recovery and insolvency, Corporate transactions, including capital raising, initial public offerings, mergers and acquisitions, restructuring, Valuations, Litigation Support, IT consulting 
where that involves the development, sale, operation of, or advice about software systems for accounting purposes, Annual financial statements and compliance, Equity and debt raising, Personal investment services, including portfolio management, Superannuation consulting and compliance services, including self-managed funds and retirement planning, Succession and estate planning, Financial planning, including cash flow management, asset protection and insurance, Risk assessment and management, Networking advice and functions, Training and educational services.

In the UK, many empirical studies show that smaller enterprises used a professional accountant as a source of advisory and support services (Berry et al, 2006). In Norway, (Gooderhametal., 2004) revealed that professional accountants are reliable providers of advisory services and support in small companies. In Australia, many claimed that external accountants have provided financial management and support services for the SME sector (Leung et al., 2008). In New Zealand, Lewis et al. (2005) found external accountants were the main source of advice in terms of frequency, usefulness and significance of advice in SME context. There seems to be a paucity of studies done in developing countries in general, and Africa in particular.

Accounting services comprises five types of services (tax consultancy, business advice, management consultancy, financing advice and IT consultancy) provided by professional accountants to SME sector which are similar to that derived from Doran, (2006). Consequently, the current study shall utilize the measurement developed by Gooderham et al. (2004), asking participants to indicate to what extent they utilize an external accountant as adviser. Arguments abound as to the role of the accountant in the growth and performance of SMEs. One such study by Peacock, (2000) assert that the accountant serves the role of an SME doctor, by detecting challenges facing individual and prescribing measures on how to deal with the challenges. The study by Peacock (2000) is supported by Drever \& Hartcher, (2003) who argue that the failure by SMEs to manage cash flow results in illiquidity and finally the demise of SMEs.

The two studies advocate for the engagement of a qualified accountant who would be instrumental in advising on the strategic response that SMEs need to take as they encounter turbulent and competitive environments. In addition, the accountant would serve the crucial role of book keeping and cash flow management. The role of the accountant would have an additional benefit of making sure that SMEs acquire the much needed finance from banks, something they can't do unless they have kept proper books of account.

Factors like inadequacy and costly of credit facilities and sources, shortage of working capital, high investment in fixed assets during start-up time, lack of record keeping, documentation and failure to analyze financial statements and the like are identified as factors that affect the performance of small business performance in Addis Ababa, Arada sub City by Hbtamu T. Proper management of fixed capital may lead to proper implementation of strategic plans. While proper management of working capital minimizes short-term obstacles to achieve competitive advantages in the market place (Habtamu T, )

\subsection{Statement of the Problem}

Many researchers conduct a study around the title of 'The role of Practicing Accounting services as an Advisory to micro and Small business enterprises' and concluded that those firms who engaged the services of a qualified accountant had significantly less incidences of illiquidity, failure, business stagnation and lack of credit access compared to those that had not.

The problem with micro and small settings is that they rarely use the services of a qualified accountant. This is demonstrated by the Okwena, Okioma \& Onsongo, (2010) results that book keeping practice of the small and medium enterprises is not adequate and this may negatively affect the financial performance of the enterprises. Berryman, (1983) also found that small business failure inevitably showed poor or careless financial management. The strategic use of a qualified accountant by small and medium enterprises is an area that has received its fair share of scholarly attention.

Other study by Breen \& Sciulli, (2002) either investigated the effect of book keeping and cash flow management as a possible cause of small and medium enterprises failure. Aritho, (2010) conducted an investigation into application of strategic management accounting in organizations by focusing on a case study of Kenya Literature Bureau and concluded that the level of adoption of strategic management accounting practices were low. However, he failed to focus on SMEs use of accounting services.

Kesseven p., (2012) conducts a study on the title of Factors affecting the adoption of formal accounting systems by micro and small business enterprises and found that size of the enterprise, ownership characteristics of the enterprises, education level of the owner and family involvement in the business affects the use of formal accounting system in Mauritius.

Tran Thi Thanh Hai , (2014) An Analysis of the Factors Affecting the Adoption of Accounting Legislation by Small and Medium-Sized Enterprises (SMES) in Vietnam have found that accounting infrastructure, mandatory compliance of these regulations, accountants, cost-benefit relationship and the accounting legislation itself are factors that affect accounting legislation by micro and small business enterprises in Vietnamese.

Busieney \& Mirie M., (2017) studies on the title of Factors influencing the use of accounting services by 
small and medium enterprises and founds that poor knowledge and competence of the owners, high competition among the SMEs, low level of compliance with accounting legislation influences the use of accounting services in Kenya and In addition, the study findings revealed that SMEs did not use accounting services.

Nelson Maseko \& Onias Manyani, (2011) Accounting practices of SMEs in Zimbabwe: An investigative study of record keeping for performance measurement (A case study of Bindura) by using questionnaires as a data collection instrument has found that the majority of SMEs do not keep complete accounting records because of lack of accounting knowledge and as a result there is inefficient use of accounting information in financial performance measurement

Bancy Wawira Muchira (2012) Record keeping and growth of micro and small enterprises, a case study of thika municipality in kenya founds that the MSEs faced various challenges common ones being lack of the recordkeeping knowledge, Time constraints and lack of knowledge on the importance of keeping the records by some of the entrepreneurs

Girmachew Kahsay \& Girma Zeleke, (2019) Factors Affecting Use of Accounting Records on Small \& Micro Enterprises (the Case of Debre Birhan City, Ethiopia) by using multiple regression analysis found that capital and access to credit did have positive relations but insignificant and on the other hand, education and age had positive and significant relation with the use of accounting records in debre birhan city, Ethiopia.

The current study tries to fill the gap from the fact that most of the conducted studies assert the importance of accounting services for micro and small businesses financial performance, but most of the time small and medium enterprises do not use such important services (Mirie M., 2017). And the failure to use such strategically important services is the cause of most micro and small business enterprises business stagnation and liquidation according to many studies reviewed from the literature. Some studies also tried to identify factors influencing the use of accounting services by SMEs outside of Ethiopia and with in Ethiopia too.

A study which comprises, family involvement in the enterprise, demographic characteristics of the enterprise, and demographic characteristics of the owner, inventory turnover period and knowledge and competence of the owners all together is not conducted yet in Dembi dollo town administration. So, the researcher has taken up this study to fill the gap and test the combined effects of these variables on the use of accounting services by micro and small business enterprises in Dembi dollo town administration.

\subsection{Objectives of the Study}

\subsubsection{General Objective of the Study}

The general objective of the study was to determine factors that affect the use of accounting services by micro and small business enterprises in Dembi dollo town administration

1.3.2 Specific Objectives of the Study

1. To determine the effect of family involvement on the use of accounting services by micro and small business enterprises (business entity concept)

2. To determine the effect of demographic characteristics of the firm on the use of accounting services by micro and small business enterprises

3. To determine the effect of demographic characteristic of owners on the use of accounting services by micro and small business enterprises

4. To determine the effect of inventory turnover period on the use of accounting services by micro and small business enterprises

1.4 Hypothesis of the Study

1. Ho: Family involvement in the business has no a significant relationship with the use of accounting services by micro and small enterprises

2. Ho: Size of the business enterprise has no significant relationship with the use of accounting services by micro and small business enterprises

3. Ho: Age of the business enterprise has no a significant relationship with the use of accounting services by micro and small business enterprises

4. Ho: Number of employees within the enterprise has no a significant relationship with the use of accounting services by micro and small business enterprises

5. Ho: Nature of the enterprise has no a significant relationship with the use of accounting services by micro and small business enterprises

6. Ho: Age of the owners/managers has no a significant relationship with the use of accounting services by micro and small business enterprises

7. Ho: Gender of the owners has no a significant relationship with the use of accounting services by micro and small business enterprises

8. Ho: Education level of the owner/manager has no a significant relationship with the use of accounting services by micro and small business enterprises 
9. Ho: Knowledge and Competency of the owner/managers has no a significant relationship with the use of accounting services by micro and small business enterprises

10. Ho: Inventory turnover period has no a significant relationship with the use of accounting services by micro and small business enterprises

\section{Empirical literature reviews}

Ahamed Al-dmour, Rand Al-dmour, Ra'ed Masa'deh, (2014) Interrelated Factors Influencing the Adoption Decision of AIS Applications by SMEs in Jordan have found that set up cost, government rules and regulations and competitive pressures affect the adaption of Accounting information system by micro and small business enterprises in Jordan by using ANOVA and T-test.

Adejare \& Abdul-Rahamon, (2014) The Analysis of the impact of Accounting Records Keeping on the Performance of the Small Scale Enterprises by using a descriptive design such as personal

Interviews and questionnaire as the major techniques for primary data collection concluded that there is a strong positive relationship between accounting records keeping and performance of small scale enterprises. Accounting records keeping is essential for decision making which invariably affects performance of small scale enterprises and recommended that the owners and managers of the small scale enterprises should embrace proper accounting records keeping practices for effective financial performance in their business.

Husin \& Ibrahim, (2014) the Role of Accounting Services and Impact on Small \& Medium Enterprises (SMEs) Performance in Manufacturing Sector from East Coast Region of Malaysia: A Conceptual Paper by developing conceptual framework highlighted the relationship between SMEs in accounting services and has an implication for accountant firms, SMEs, academic and also to the company involve and handle in service quality.

Tran Thi Thanh Hai , (2014) An Analysis of the Factors Affecting the Adoption of Accounting Legislation by Small and Medium-Sized Enterprises (SMES) in Vietnam have found that accounting infrastructure, mandatory compliance of these regulations, accountants, cost-benefit relationship and the accounting legislation itself are factors that affect accounting legislation by micro and small business enterprises in Vietnamese.

Kesseven p., (2012) conducts a study on the title of Factors affecting the adoption of formal accounting systems by micro and small business enterprises and found that size of the enterprise, ownership characteristics of the enterprises, education level of the owner and family involvement in the business affects the use of formal accounting system in Mauritius.

Busieney \& Mirie M., (2017) studies on the title of Factors influencing the use of accounting services by small and medium enterprises and founds that poor knowledge and competence of the owners, high competition among the SMEs, low level of compliance with accounting legislation influences the use of accounting services in Kenya and In addition, the study findings revealed that SMEs did not use accounting services.

Nelson Maseko \& Onias Manyani, (2011) Accounting practices of SMEs in Zimbabwe: An investigative study of record keeping for performance measurement (A case study of Bindura) by using questionnaires as a data collection instrument has found that the majority of SMEs do not keep complete accounting records because of lack of accounting knowledge and as a result there is inefficient use of accounting information in financial performance measurement

Bancy Wawira Muchira (2012) Record keeping and growth of micro and small enterprises, a case study of thika municipality in kenya founds that the MSEs faced various challenges common ones being lack of the recordkeeping knowledge, Time constraints and lack of knowledge on the importance of keeping the records by some of the entrepreneurs

Girmachew Kahsay \& Girma Zeleke, (2019) Factors Affecting Use of Accounting Records on Small \& Micro Enterprises (the Case of Debre Birhan City, Ethiopia) by using multiple regression analysis found that capital and access to credit did have positive relations but insignificant and on the other hand, education and age had positive and significant relation with the use of accounting records in debre birhan city, Ethiopia. 


\subsection{Conceptual Framework of the Study}

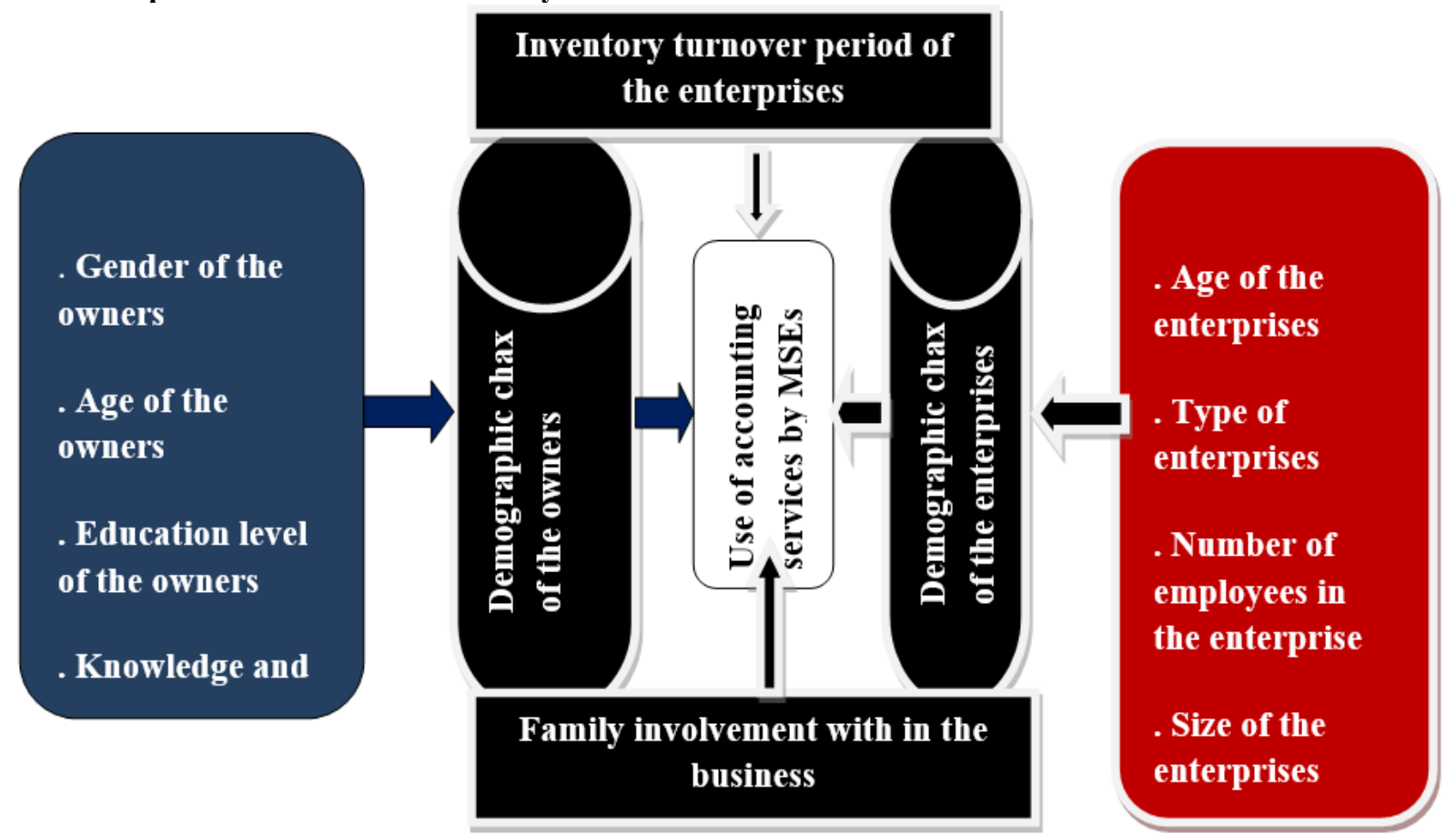

Fig. 1: Conceptual framework, developed for this study by the researcher

Table2.2 Summary of Empirical Related Literature Review

\begin{tabular}{|c|c|c|c|c|c|c|c|c|c|c|c|c|}
\hline \multirow{2}{*}{$\begin{array}{l}\text { Authors name } \\
\text { and publication } \\
\text { year }\end{array}$} & \multirow[b]{2}{*}{ 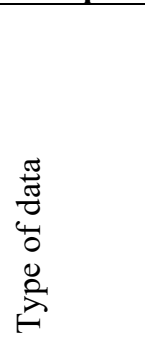 } & \multirow[b]{2}{*}{ 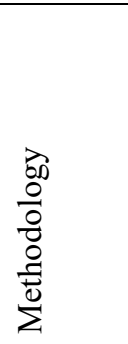 } & \multicolumn{7}{|c|}{ Empirical Results } & \multirow[b]{2}{*}{$\begin{array}{l}\overrightarrow{0} \\
\stackrel{0}{0} \\
0 \\
\tilde{N}\end{array}$} & \multirow[b]{2}{*}{ 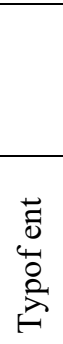 } & \multirow[b]{2}{*}{$\underset{\omega}{\varpi}$} \\
\hline & & & 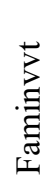 & $\bar{\infty}$ & 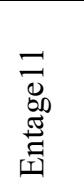 & 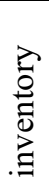 & $\begin{array}{l}\stackrel{0}{\Xi} \\
\Xi \\
\Xi\end{array}$ & 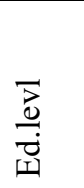 & $\begin{array}{l}\cup \\
\forall \\
\forall\end{array}$ & & & \\
\hline $\begin{array}{l}\text { Girmachew K. \& } \\
\text { Girma Z., (2019) }\end{array}$ & $\begin{array}{l}\text { Cross } \\
\text { sectional }\end{array}$ & OLS & & sig & & & & sig & & & & \\
\hline $\begin{array}{l}\text { Tran Thi Thanh } \\
\text { Hai (2015) }\end{array}$ & $\begin{array}{l}\text { Cross } \\
\text { section }\end{array}$ & OLS & & & & & & & & & sig & \\
\hline Busieney \& Mirie & $\begin{array}{l}\text { Cross } \\
\text { section }\end{array}$ & OLS & & & & & & & Sig & sig & & \\
\hline \begin{tabular}{ll}
\multicolumn{2}{l}{ Ahamed A., Rand } \\
A \& Ra'ed \\
Masa'deh
\end{tabular} & $\begin{array}{l}\text { Cross } \\
\text { section }\end{array}$ & $\begin{array}{l}\text { T-test } \\
\& A N O\end{array}$ & & & & & & sign & Sig & & & insig \\
\hline K Padachi,( 2012) & $\begin{array}{l}\text { Cross } \\
\text { section }\end{array}$ & Logit & sig & & Insig & & & Insig & & insig & & \\
\hline $\begin{array}{l}\text { Le TTO, Bui TN, } \\
\text { Tran MD (2017) }\end{array}$ & $\begin{array}{l}\text { Cross } \\
\text { section }\end{array}$ & $\begin{array}{l}\text { PCA \& } \\
\text { OLS }\end{array}$ & & Insig & Insig & & & & Insig & insig & & \\
\hline $\begin{array}{l}\text { Bancy Wawira } \\
\text { Muchira (2012) }\end{array}$ & $\begin{array}{l}\text { Cross } \\
\text { section }\end{array}$ & - & & & & & & & Sig & & & \\
\hline $\begin{array}{l}\text { Nelson Maseko \& } \\
\text { Onias Manyani, } \\
(2011)\end{array}$ & $\begin{array}{l}\text { Cross } \\
\text { section }\end{array}$ & - & & & & & & & Sig & & & \\
\hline
\end{tabular}

\section{Research Methodology}

\subsection{Description of the Study Area}

The focus of the study was in Dembi dollo town administration. Dembi dollo formerly sayo is a market town and 
separate woreda in south western Ethiopia. It is mostly known by its gold and busy cash crop business including coffee arabica. It is the capital of qelam wolega zone of the oromia region and it exists on the distance of $631 \mathrm{kms}$ from Addis Ababa, the center of Ethiopia.

As any other part of the country in dembi dollo town administration, micro and small business enterprises are the source of employment and income for the people. The business activities include manufacturing (tailors, wood work, metal work and traditional jewelries), construction, services (municipality services, barber houses, beauty salon, hotels and restaurants, maintenance services), urban agriculture and trade.

\subsection{Research Design}

This study will employ descriptive and explanatory research designs, which is used when the problem has been defined specifically and where the researcher has certain issues to be described by the respondents about the problem (Kothari, 2004).

Descriptive research design will be used in order to explain and describe the factors that affect the use of accounting services by micro and small business enterprises in Dembi dollo town administration. The study will also use cross-sectional type of research design; because the data will be collected from the sample participants who take part in the study once only.

\subsection{Research Approach}

The researcher used a mixed research approach; i.e. both qualitative and quantitative research approaches. The quantitative approach provides an objective measure of reality, on the other hand, the qualitative approach allows the researcher to explore and better understand the complexity of a phenomenon. Both quantitative and qualitative research approaches may have their own strengths and limitations. According to Sale et al, (2002) the advantage of a quantitative research approach may be limitations for a qualitative approach and vice versa. So the researcher was supposed to use a mixed research approach in order to fill the limitation of one approach by the strength of the other approach.

\subsection{Target Population of the Study}

The target populations for this study was 3361(manufacturing 1768, construction 326, service 627, urban agriculture 158 and merchandising 482 micro and small business enterprises which exist in Dembi dollo town administration and formally registered by trade and industry office of the town.

\subsection{Sample Size}

At a confidence level of $95 \%$, and the margin of error of $5 \%$, to obtain a sample size that has an adequate size relative to the goals of the study, the researcher adopted Yamane's formula as follows:

$\mathrm{n}=\frac{\mathrm{N}}{1+N(0.05) 2}$

Where; 'n' = sample size, "N" = population size and, "e" = margin of error (Yamane, 1967).

$\mathrm{n}=\frac{3361}{1+3361(0.05) 2}=358$

A sample size of 358 respondents was used to analyze and achieve the objective of the study.

Table3.3 Proportionate Sample Size Determinations from Each Stratum

\begin{tabular}{|l|l|l|}
\hline Category & Target population & Sample size \\
\hline Manufacturing & 1768 & $188=(1768 / 3361 * 358)$ \\
\hline Construction & 326 & $35=(326 / 3361 * 358)$ \\
\hline Service & 627 & $67=(627 / 3361 * 358)$ \\
\hline Urban agriculture & 158 & $17=(158 / 3361 * 358)$ \\
\hline Merchandising & 482 & $51=(482 / 3361 * 358)$ \\
\hline Total & 3361 & 358 \\
\hline
\end{tabular}

Source: developed for this study by the researcher

\subsection{Sampling Technique of the Study}

The study used stratified probability sampling technique which is one of the sampling techniques under probability sampling to select the enterprises and to select the respondents the researcher will use simple random sampling technique. Stratified probability sampling method was used because by nature, small enterprises exist in the form of strata. So using stratified probability sampling technique is important here to incorporate all sectors of the business proportionally. Simple random sampling technique was used in order to avoid biases and to give equal chance to the sample participants. 


\subsection{Type and Source of data}

The researcher used both primary and secondary types of data. The source of the data was micro and small business enterprise owners/managers which exist in Dembi dollo town administration.

\subsection{Methods of Data Collection}

The data was collected through questionnaires and unstructured interview from the sample respondents of the study.

\subsection{Method of Data Analysis}

The raw data obtained from the respondents was analyzed and interpreted by running STATA version 12 . Both statistical analysis such as, frequency tables and binary logistic regression analysis methods were used as data analysis Techniques.

The focus of this study was to find out the link between independent variables such as, inventory turnover period, knowledge and competency of owner/manager, size of the business, age of the business and education level of the owners with the dependent variable the use of accounting services by micro and small business enterprises.

\subsection{Conceptual Model}

The following conceptual model was adopted in the study where the use of Accounting services (UAS) is a function of family involvement (FI), Inventory turnover period (ITP), demographic characteristics of the enterprise (DCE) and demographic characteristics of the owners.

$\mathrm{UAS}=\mathrm{f}(\mathrm{FI}, \mathrm{ITP}, \mathrm{DCE}, \mathrm{DCO}, \mathrm{CO})$

Where; AS = Use of accounting services by MSE, FI = Family involvement in the business, ITP = Inventory turnover period, DCE = Demographic characteristics of the business (Age of the business, size of the business, nature of the business and number of employees within the business), $\mathrm{DCO}=$ Demographic characteristics of the owner (gender of the owner, age of the owner, education level of the owners and knowledge and competence of the owners)

\subsection{Analytical Model}

The following binary logistic regression model was used to perform the data analysis $\mathrm{UAS}=\beta 0+\beta 1 \mathrm{FI}+\beta 2 \mathrm{AE}+\beta 3 \mathrm{SE}+\beta 4 \mathrm{TE}+\beta 5 \mathrm{NE}+\beta 6 \mathrm{SO}+\beta 7 \mathrm{AO}+\beta 8 \mathrm{ELO}+\beta 9 \mathrm{KCO}+\beta 10 \mathrm{ITP}+\varepsilon$

Where, $\mathrm{B} 0=$ the constant, $\mathrm{FI}=$ family involvement, $\mathrm{AE}=$ age of the enterprise, $\mathrm{SE}=$ size of the enterprise, $\mathrm{TE}=$ nature of the enterprise, $\mathrm{NE}=$ number of employees, $\mathrm{SO}=$ gender of the owners, $\mathrm{AO}=$ age of the owners, $\mathrm{ELO}=$ education level of the owners, $\mathrm{KCO}=$ knowledge and competence of the owners, ITP $=$ inventory turnover period .

\subsection{Ethical Consideration}

Standard ethical guidelines and procedures were followed for gathering data from each of the small business enterprise operators who take part in the study. Each of the participants was take part in the study voluntarily and an explanation was provided to each of the respondents about the purpose of the study, along with their right to drop out of the study without having to explain why. They were informed that responses obtained from each participant will be kept in confidence and respondents will not be exposed to any risk as a result of taking part in the study.

\section{Results and Discussion}

\subsection{Logistic Regression Results}

Binary logit model was employed to analyze the effect of constraints like family involvement, inventory turnover period, education level of the owners, size of the enterprises, age of the enterprises, knowledge and competence of the owners, number of employees within the enterprises, sex of the owners and type of the enterprises on the use of accounting services. To measure the perception the dummy variable use of accounting services (useofaccs) is constructed as dummy one if operators use accounting services in their enterprises and zero otherwise. This shows the probability that the enterprise will experience the application of accounting services while controlling for other factors. 


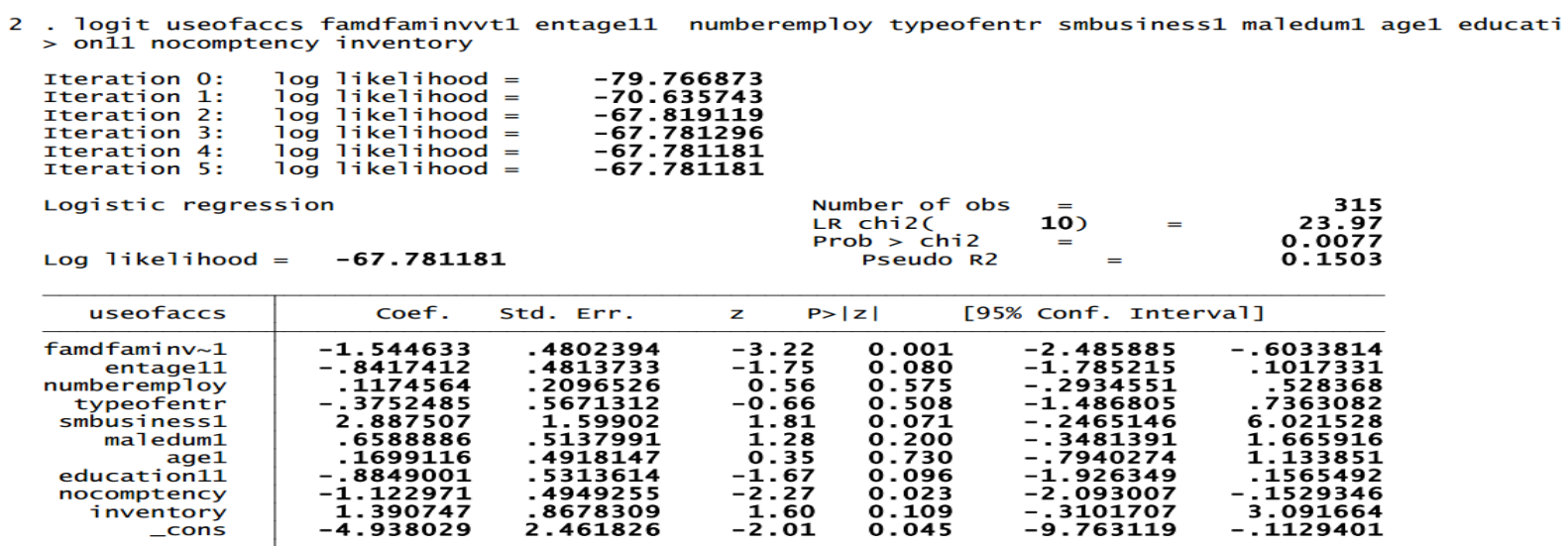

Concerning to the background of the owners the variable education is statistically significant at $10 \%$. The variable education is negative indicating that a probability that the owners with education levels of below grade 12 are less likely to use accounting services in there enterprises by 0.8849 times than diploma and degree holders.

Regarding the characteristics of enterprises, enterprise age (entage11) is negative and statistically significant at $10 \%$, which indicates that young enterprises are less likely to use accounting services by 0.8417 times than older ones.

From the other variables family involvement with in the operation of the business (famivvt1) is negative and significant at 5\% which indicates that enterprises which are operated and managed by family members are less likely to use accounting services by 1.5446 times than others. Size (smbusiness 1 ) of the enterprises is positive and significant at $10 \%$ which indicates that business enterprises with small size are more likely to use accounting services 2.8875 times than micro business enterprises.

The other variable knowledge and competency of the owners (nocomptency) is negative and significant at 5\% which indicates that the owners that do not have enough knowledge and skill to use accounting services are less likely to use accounting services in there enterprises by 1.12297 times than those who have a knowledge and skill to use accounting services in their enterprises.

\subsection{Testing the Hypothesis and Discussion of Findings}

Each hypothesis was tested and interpreted from the above model as follows. The pseudo R Square is $15.03 \%$ which shows that $15.03 \%$ of the increase or decrease in the use of accounting services was explained by the independent (or predictor) variables in this model. The "Hosmer and Lemeshaw" as well as Pearson model fit test yielded a chi-square value of 3.90 with p-value of 0.8662 and 206.91 and 0.8607 respectively, suggesting the logistic model fits the data well.

Sex of the owners (maledum1): for sex of the owners have value of $\mathrm{B}=0.6588$, and $\mathrm{P}$ value $=.20$. This shows that sex of the owners do not have a significant relationship with the use of accounting services by MSE. Hence, the researcher fails to reject Ho of sex of the owners do not have any significant relationship with the use of accounting services by MSEs.

Age of the owners (age1): the odds ratio of the variable age 1 is $\mathrm{B}=0.1699$ and $\mathrm{P}=0.73$. This shows that age of the owners do not have a significant effect on the use of accounting services by MSEs. Hence, the researcher fails to reject the null hypothesis of (Ho) that age of the owners does not have a significant effect on the use of accounting services by MSEs.

This finding is consistent with the findings of Kesseven Padachi, (2012) in which age of the owner manager was reported as a non significant factor for the use of accounting services by micro and small business enterprises.

Education level of the owners (education1): as shown on the above regression result the beta coefficient for education 1 is -0.8849 , and the ' $\mathrm{P}$ ' value is 0.096 which means that the owners with education level of below grade 12 uses accounting services less than diploma and degree holders by 0.8849 times. And on the other way the owners with education level of greater than grade 12 or that holds diploma and degree uses accounting services 0.8849 times higher in comparison with those who learn below grade 12 . This shows that education is a significant contributor for the use of accounting services by MSEs in Dembi dollo town administration. Thus, the researcher rejects the null hypothesis (Ho) of that education level of the owners do not have any significant relationship with the use of accounting services by MSEs.

This result is consistent with Girmachew Kahsay \& Girma Zeleke, (2019) in which education was fund as positive and significant factor for the use of accounting record by SMEs. On the other hand this finding contradicts with the findings of Kesseven Padachi, (2012) in which education of the owner manager was reported as a non significant factor for the use of accounting services by micro and small business enterprises.

Age of the enterprises (entage11): the variable here age which is related with demographic characteristics of the 
enterprises have a value of $\mathrm{B}=-0.8417$ and ' $\mathrm{P}$ ' $=0.080$, which means that enterprises below 5 ages uses accounting services 0.8417 times less than enterprises with ages greater than 5 . Or on the other way enterprises that have greater than age 5 uses accounting services 0.8417 times higher in comparison with enterprises that have below age 5. This shows that age of the enterprises is a significant contributor for the use of accounting services by MSEs in Dembi dollo town administration. Thus, the researcher rejects the null hypotheses (Ho) of that age of the enterprises do not have any significant relationship with the use of accounting services by MSEs.

This result is consistent with the result of Girmachew Kahsay \& Girma Zeleke, (2019) result in which age of the enterprises was reported as a positive and significant factor for the use of accounting services by micro and small business enterprise in debre birhan city.

And this result is consistent with the theory of scholars that Age of the enterprises can affect the use of accounting services by MSEs in the sense that MSEs that have been in existence for a short period of time may find it difficult to install or apply accounting services because they have not been tried and tested compared to their counterparts who have been in existence for longer (Beck, Thorsten et al. 2005).

Type of enterprises (typeofenter): Type of the enterprises or nature of enterprises have $\mathrm{B}=-0.3752$ and $\mathrm{P}$ value of $=0.508$ from the regression result. This shows that type of the enterprises do not have a significant relationship with the use of accounting services by MSEs. Hence, the researcher fails to reject Ho of that the types of enterprises do not have any significant relationship with the use of accounting services by MSEs.

Number of employees (numberemploy): from the regression result number of employees have a value of ' $B$ ' = 0.1174 and ' $\mathrm{P}$ ' value $=0.575$ which means that the number of employees within the enterprise do not have a significant relationship with the use of accounting services by MSEs in the town. So, the researcher fails to reject the null hypotheses of (Ho) that numbers of employees within the enterprise do not have any significant relationship with the use of accounting services by MSEs in dembi dollo town administration.

Family involvement (famdfamin 1): As shown on the above regression result family involvement with in the business have a $\mathrm{B}$ value of $=-1.5446$ and $\mathrm{P}$ value $=0.001$. It would mean that the odds ratio of decreasing in the use of accounting services that operate by family members is 1.5446 times higher in comparison with enterprises that are operated by other than family members. On the other way enterprises that are operated by outside of the family members uses accounting services 1.5446 times higher than those operated by family members. This shows that family involvement with in the operation of the business is a significant factor which dictates the use of accounting services by MSEs in Dembi dollo town administration. Thus, the researcher rejects the null hypotheses (Ho) of that family involvement do not have any significant relationship with the use of accounting services by MSEs

This result is consistent with the results of Kesseven Padachi, (2012) in which the variable family involvement with in the business was found as negative and statistically significant factor for the use of accounting services by micro and small business enterprises.

Knowledge and competency (nocomptency): knowledge and skill of the owners in the application of accounting services has a $B$ value of $=-1.1229$ and $P$ value of $=0.023$. It shows that the odds ratio of decreasing in the use of accounting services by enterprise owners that do not have a knowhow about the use of accounting services and its application is 1.1229 times higher in comparison with enterprises owners that have a know how knowledge about accounting services and its application. On the other way owners that have a skill about the use of accounting services use it 1.1229 times higher than those who do not have a skill and competence to use accounting services in their enterprises. Based on this the researcher rejects the null hypotheses of (Ho) knowledge and competence of the owners does not have a significant relationship with the use of accounting services by MSEs

The result is consistent with Busieney Stephen Kipsang \& Mirie Mwangi, (2017) and Girmachew Kahsay \& Girma Zeleke, (2019) in which that knowledge and competence of the respondents was poor and as a result it affects the use of accounting services by MSEs in Kenya and Debre birhan city respectively.

Inventory turnover period (inventory): inventory turnover period have a value of $\mathrm{B}=1.39$ and $\mathrm{P}$ value $=0.109$ which means that inventory turnover period do not have a significant relationship with the use of accounting services by MSEs in the town. So, the researcher fails to reject the null hypotheses of (Ho) that inventory turnover period of the enterprise do not have any significant relationship with the use of accounting services by MSEs in dembi dollo town administration

Size of the enterprise (smbusiness1): the odds ratio of the variable size of enterprises is $\mathrm{B}=2.8875$ and $\mathrm{P}=$ 0.071 . This indicates that the increase in the use of accounting services that have small scale business enterprises is 2.8875 times higher than those who have micro business enterprises and the $\mathrm{P}$ value shows that sizes of enterprises have a significant effect on the use of accounting services by micro and small business enterprises. Thus, the researcher rejects the null hypotheses (Ho) of that size of enterprises do not have a significant effect on the use of accounting services by MSEs.

This result is consistent with the results of Busieney Stephen Kipsang \& Mirie Mwangi, (2017) in which growth in size of the enterprises was positively and significantly related with the use of accounting services by MSEs in Kenya. On the other hand this finding contradicted with the findings of Kesseven Padachi, (2012) in which size 
of the enterprises was insignificant factor for the use of accounting services by MSEs

\subsection{Summary of Results and Hypotheses Confirmation}

\begin{tabular}{|l|l|l|}
\hline Variable & 'P' Value & Decision \\
\hline Family involvement (famdfaminv $\sim 1)$ & 0.001 & Reject Ho @ 5\% \\
\hline Age of the enterprises (entage11) & 0.080 & Reject Ho @ 10\% \\
\hline Number of employees (numberemploy) & 0.575 & Fail to reject Ho \\
\hline Size of the enterprise (smbusiness1) & 0.071 & Reject Ho @ 10\% \\
\hline Nature of the business (typofentr) & 0.508 & Fail to reject Ho \\
\hline Gender of the owners (maledum1) & 0.200 & Fail to reject Ho \\
\hline Age of the owners (age1) & 0.730 & Fail to reject Ho \\
\hline Education level of the owners (education11) & 0.096 & Reject Ho @ 10\% \\
\hline Knowledge and competence of the owners (nocomptence) & 0.023 & Reject Ho @ 5\% \\
\hline Inventory turnover period (Inventory) & 0.109 & Fail to reject Ho \\
\hline
\end{tabular}

\section{Conclusions and Recommendations}

\subsection{Conclusions}

The general objective of the study was to determine factors that affect the use of accounting services by micro and small business enterprises in dembi dollo town administration. In order to achieve the major objective, there were four specific objectives.

The first specific objective of the study was to determine the effect of family involvement on the use of accounting services by MSEs in dembi dollo town administration. Accordingly, the study identified as; businesses that are operated by family members are less likely to use accounting services which is compared with those operated by outside of the family members. Or businesses that are operated by other than family members are more likely to use accounting services than businesses that are operated by family members. This one will be due to the reason that the argument of 'business entity concept' is a starting point for a formal accounting system and that is normally absent in very small and small firms. Further, the tax authorities normally club business income with individual/family income if the firm is proprietorship or partnership. Thus, unless there is an incentive to separate business from family, micro and small business enterprises will not have any incentive to have separate accounting systems and tax authorities can consider the same.

The second objective of the study was to determine the effect of demographic characteristics of the enterprise on the use of accounting services by micro and small business enterprises in dembi dollo town administration. Accordingly, the study identified as, size of the enterprises and age of the enterprises significantly affects the use of accounting services in the town in the sense that when the size of enterprises increases from micro to small their incentive to use accounting services increases and as the same time when the age of the enterprises increases their incentive to use accounting services increases. But the other variable numbers of employees within the enterprises do not have any effect on the use of accounting services according to this study.

The third specific objective of the study was to determine the effect of demographic characteristics of the owners on the use of accounting services by MSEs in Dembi dollo town administration. Accordingly, the study identified as; education level and knowledge and competence of the owners affect the use of accounting services within the town significantly, in the sense of that when education level of the owners increases, the incentive to implement or use accounting services increases and when education level of the owners decreases then the use of accounting services by micro and small business enterprises decreases and if the owners has a knowledge about accounting services and their advantage and at the same time if they have a skill to implement it then, in will increase the use of accounting services by MSEs within the town and if they do not have knowledge and skill about accounting services and a skill to implement them it will negatively affect the use of accounting services within the town and on the other hand gender and age of the owners do not affect the use of accounting services within the town according to the result of this study.

The fourth specific objective of the study was to determine the effect of inventory turnover period of enterprises on the use of accounting services within the town. But by chance this variable is not significant so, Inventory turnover period do not have any significant effect on the use of accounting services in dembi dollo town administration according to the results of this study.

\subsection{Recommendations}

The main objective of the study was to identify factors that affect the use of accounting services by micro and small business enterprises in Dembi dollo town administration and suggest possible recommendations to overcome the problems. Therefore, based on the findings of the study, the following recommendations are suggested to the concerned bodies. 
It's argued that the 'business entity concept' is a starting point for a formal accounting system and that is normally absent in very small and small enterprises. So, the primary method or the first step to go forward and suggest MSE owners about the use of accounting services is to give them the basic business entity concept training. Business entity concept is simply the separation of the owner's personal expenses from the business and the transaction of one business should be separated from the other business if any. So dembi dollo town micro and small enterprises office should give a basic business training to the concerned business enterprises not only about the business entity concept but also other principles and concepts of the business like ongoing concern, historical cost principle and the types of business enterprises with their advantages and disadvantages through the use of personnel's that are professional about this concern.

To adopt and implement accounting services within one enterprise there is so called software which is Peachtree accounting. If one has enough knowledge about Peachtree accounting and a skill how to implement it, then the use of accounting services would be too easy. So dembi dollo town micro and small enterprises office should give an adequate training to the concerned enterprises about the software, its installation and its advantages by using academicians from Dembi dollo university or Rift valley or any one from anywhere who can give enough clarification and knowledge about the software, its installation and advantages.

And finally the researcher suggests that the enterprises office should advice the owners of micro business enterprises to upgrade from micro to small because the owners of small enterprises are more likely to use accounting services than micro enterprise owners in the sense that, when the transaction and employees of enterprises increases then they would intend to use accounting services. As the same time the training should include the advantages of proper record keeping regarding with tax expenses and business profitability.

\section{References}

Ademola, G. O., Samuel O. J.\& Ifedolapo O., (2012), The Roles of Record Keeping In the Survival and Growth of Small Scale Enterprises in Ijumu Local Government Area of Kogi State. Global Journal of Management and Business Research Volume 12 Issue 13 Version 1.0 Year 2012

Baker, R.E., Lembke, V.C ., King, T.E. and Jeffrey, C.G. (2008). AdvancedAccounting TT\& edition. McGrawHill/Irwin,

Baysa and Lupisan. (2008). Advanced Accounting. Vol 1 and 2. Accounting for Partnership and Corporation

Breen, J., and Sciulli, N., (2002) "Use of Computerised Record Keeping in Small Business" CPA Australia: Small Business Research Program. Published CPA Australia September 2002

Busieney Stephen Kipsang, Mirie Mwangi, (2017) Factors Influencing the Use of Accounting Services By Small and Medium Enterprises in, Journal of Accounting, Vol.1, Issue No.1, pp44 - 59, Kenya

Carnegie. G., Jones, S., Norris, G., Wigg, R. \& Williams, B. (1999), Accounting Financialand Organisational Decision making, (McGraw Hill Sydney)

Crane, M.L., (1997) Record Keeping. Essential to Risk Management NCIS November, 1997

Donovan G., Carroll P. and Gibson K. (2010) Interactional Trade in Australian Accounting Services and Australian Accounting Firms: State of Play. International Review of Business Research Papers Volume 6 Number 5 October 2010 Pp. 145 - 159

Endalkachew M., (2008) Underlying Causes of Micro and Small Business Failures in Addis Ketema Sub City: masters degree thesis, Addis Ababa University

Girmachew Kahsay \& Girma Zeleke, (2019) Factors Affecting Use of Accounting Records on Small \& Micro Enterprises (the Case of Debre Birhan City, Ethiopia). Journal of Investment and Management. Vol. 8, No. 1, 2019, pp. 1-7. doi: 10.11648/j.jim.20190801.11

Gooderham, P. N., Tobiassen, A., Doving, E., \&Nordhaug, O. (2004).Accountants as sources of business advice for small firms. International Small Business Journal, 22(1), 5-22.

Habtamu T., (2012) Challenges and Opportunities of Small and Medium Scale Enterprises (SMEs) in Addis Ababa (The Case of Arada Sub City): MBA thesis

Jayabalan, J., Raman, M., Dorasamy, M., \& Ching, N. K. C. (2009). Outsourcing of Accounting Functions amongst SME Companies in Malaysia: An Exploratory Study. Accountancy Business and the Public Interest, 8(2), 96114.

Kesseven Padachi, (2012) Factors Affecting the Adoption of Formal Accounting Systems by SMEs, Business and Economics Journal, Vol. 2012: BEJ-67

Lewis, K., Massey, C., Ashby, M., Coetzer, A., \& Harris, C. (2005). Who? When? Why? - New Zealand SME owner-managers assess their Business Assistance Interactions,Paper presented at the 8th Annual SEAANZ Conference. Armidale, 25-28 September.)

Okwena K. D.,Okioma T. and Erick N. O. (2010), An assessment of the effect of proper book keeping practices on the financial performanceperspectives from small and medium scale business enterprises in Kisii municipality, Kisii University College Journal, Kisii. Kenya 
Appendix I: Operating Definition of Dependent and Independent Variables

\begin{tabular}{|c|c|c|c|c|}
\hline Variable & $\mathrm{N}$ & Variable definition & Measurement scale & Mean \\
\hline maledum 1 & 315 & Gender of the owners & Dichotomous $(1=$ male and $(0=$ female $)$ & \\
\hline age1 & 315 & Age of the owners & Ordinal $(1=$ from $15-30,0=$ otherwise $)$ & \\
\hline education 11 & 315 & Education level of the owners & $\begin{array}{l}\text { Ordinal }(1=\text { if below grade } 12,0= \\
\text { otherwise })\end{array}$ & \\
\hline entage11 & 315 & Age of the enterprises & Ordinal $(1=$ from $1-5,0=$ otherwise $)$ & \\
\hline Numberemploy & 315 & $\begin{array}{l}\text { Number of employees within the } \\
\text { enterprises }\end{array}$ & Ordinal $(1=$ from $1-5,0=$ otherwise $)$ & \\
\hline Typeofentr & 315 & Type of enterprises & Nominal( $1=$ manufacturing, $0=$ otherwise $)$ & \\
\hline famdfaminv $\sim 1$ & 315 & $\begin{array}{l}\text { Family involvement in the } \\
\text { operation of the business }\end{array}$ & $\begin{array}{l}\text { Dichotomous }(1=\text { operated by family } \\
\text { member, } 0=\text { operated by others) }\end{array}$ & \\
\hline Inventory & 315 & $\begin{array}{l}\text { Inventory turnover period of } \\
\text { enterprises }\end{array}$ & Ordinal $(1=$ fast, $0=$ other wise & \\
\hline Nocomptency & 315 & $\begin{array}{l}\text { Knowledge \& competence of } \\
\text { the owners to use accounting } \\
\text { services }\end{array}$ & $\begin{array}{l}\text { Dichotomous } \\
(1=\text { have competency, } 0=\text { do not no } \\
\text { competency) }\end{array}$ & \\
\hline smbusiness 1 & 315 & Size of the enterprise & Nominal $(1=$ small, $0=$ micro $)$ & \\
\hline Useofaccs & 315 & Use of accounting services & $\begin{array}{l}\text { Dichotomous } \\
(1=\text { yes, } 0=\text { no })\end{array}$ & \\
\hline
\end{tabular}

\section{Appendix II: Logit Estimate: Binary Logistic Regression Results}

- Togit useofaccs famdfaminvvt1 entage11 numberemploy typeofentr smbusiness1 maledum1 age1 educati $>$ on11 nocomptency inventory

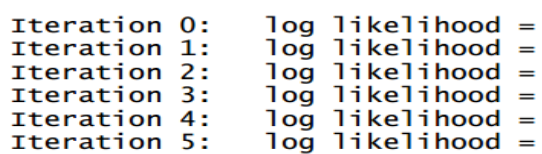

\begin{tabular}{|c|c|c|c|c|c|c|}
\hline useofaccs & coef. & Std. Err. & $z$ & & $\%$ conf. Inte & a1] \\
\hline $\begin{array}{r}\text { famdfaminv 1 } \\
\text { entage11 } \\
\text { numberemp1oy } \\
\text { typeofentr } \\
\text { smbusiness } 1 \\
\text { maledum1 } \\
\text { age1 } \\
\text { education } 11 \\
\text { nocomptency } \\
\text { inventory } \\
\text {-cons }\end{array}$ & $\begin{array}{r}-1.544633 \\
-.8417412 \\
-1174564 \\
-.3752485 \\
2.887507 \\
-6588886 \\
-1699116 \\
-.8849001 \\
-1.122971 \\
1.390747 \\
-4.938029\end{array}$ & $\begin{array}{l}.4802394 \\
.4813733 \\
.2096526 \\
.5671312 \\
1.59902 \\
.5137991 \\
.4918147 \\
.5313614 \\
.4949255 \\
.8678309 \\
2.461826\end{array}$ & $\begin{array}{r}-3.22 \\
-1.75 \\
0.56 \\
-0.66 \\
1.81 \\
1.28 \\
0.35 \\
-1.67 \\
-2.27 \\
1.60 \\
-2.01\end{array}$ & $\begin{array}{l}0.001 \\
0.080 \\
0.575 \\
0.508 \\
0.071 \\
0.200 \\
0.730 \\
0.096 \\
0.023 \\
0.109 \\
0.045\end{array}$ & $\begin{array}{l}-2.485885 \\
-1.785215 \\
-.2934551 \\
-1.486805 \\
-.2465146 \\
-.3481391 \\
-.7940274 \\
-1.926349 \\
-2.093007 \\
-.3101707 \\
-9.763119\end{array}$ & $\begin{array}{r}-.6033814 \\
.1017331 \\
.528368 \\
.7363082 \\
6.021528 \\
1.665916 \\
1.133851 \\
-1565492 \\
-.1529346 \\
3.091664 \\
-.1129401\end{array}$ \\
\hline
\end{tabular}

Appendix III: Model fit test: Hosmer - Lemeshow

- estat gof, group(10)

\section{Logistic model for useofaccs, goodness-of-fit test}

$\begin{array}{cc}\text { (Table collapsed on quantiles of estimated probabilities) } \\ \text { number of observations }= & \mathbf{3 1 5} \\ \text { number of groups }= & \mathbf{1 0} \\ \text { Hosmer-Lemeshow chi2 }(\mathbf{8})= & \mathbf{3 . 9 0} \\ \text { Prob }>\text { chi2 }= & \mathbf{0 . 8 6 6 2}\end{array}$


Appendix IV: Multicollinearity: pearson correlation

- pwcorr famdfaminvvt1 entage11 numberemploy typeofentr smbusiness1 maledum1 age1 education11 noc $>$ mptency inventory

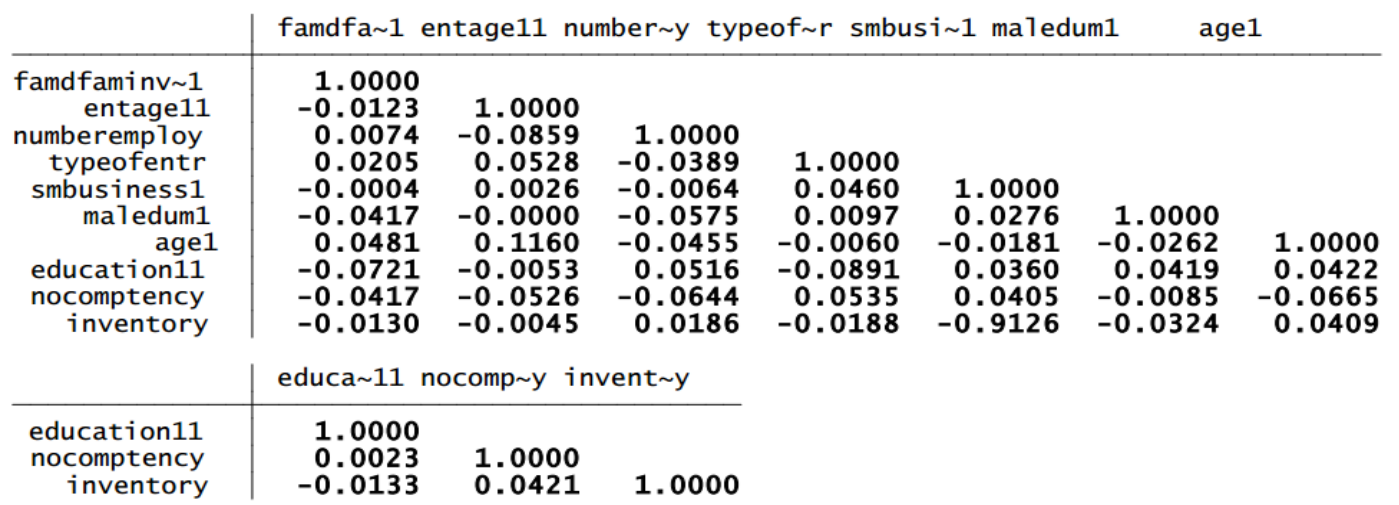

Appendix V: Model Specification Test: Link Test

\section{- Tinktest}

Iteration 0: $\log 1$ ikelihood $=$ Iteration 1: $\quad$ log likelihood = Iteration 2: 1 og likelihood = Iteration 3: log likelihood = Iteration 4: log likelihood $=$ Iteration 5: $\log$ 1ikelihood =

Logistic regression

Log 1 ikelihood $=\quad-67.455907$

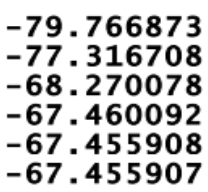

Number of obs

LR chi2C

2)

315

Prob > chi2

Pseudo R2

\begin{tabular}{r|rrrrr}
\hline useofaccs & Coef. & Std. Err. & z & P $>|z|$ & [95\% Conf. Interval] \\
\hline _hatsq & $\mathbf{1 . 5 3 5 3 4 9}$ & $\mathbf{6 9 4 7 9 6}$ & $\mathbf{2 . 2 1}$ & $\mathbf{0 . 0 2 7}$ & $\mathbf{. 1 7 3 5 7 3 8}$ \\
_cons & $\mathbf{. 1 1 5 8 0 4 9}$ & $\mathbf{. 1 3 8 1 8 4 1}$ & $\mathbf{0 . 8 4}$ & $\mathbf{0 . 4 0 2}$ & $\mathbf{- 1 5 9 7 1 2 4}$ \\
\hline
\end{tabular}

